\title{
AN AFTERNOON AMONG THE BUTTERFLIES OF
}

\section{THURSDAY ISLAND.}

By Gervase F. Mathew, R.N., F.L.S., F.Z.S., F.R.G.S., \&c.

The following account of an afternoon's collecting among the butterflies of Thursday Island, on 18th of April 1885, may perhaps be of irterest, as it is a spot, I suspect, which is not often visited by an entomologist.

Thursday Island is the central and smallest of a group of islands lying in Torres Straits, off the North Coast of Australia, and situated between latitude $10 \cdot 30$ and 10.58 south, and 146.6 and $142 \cdot 20$ east longitude. The other islands of the group are Hammond, Goode, Wednesday, Friday, Horn, and Prince of Wales Islands, with numerous small islets. Prince of Wales Island is the largest, being eleven miles long, by ten miles broad. They are all hilly, and the hills, from the sea, appear to be densely wooded, as are also the valleys between the hills. Most of the islands possess numerous small bays, some of them with an ample sandy beach, while others are fringed with belts of mangrove bushes. In some of the islands, between the ranges of hills, there are wide plains but thinly wooded with eucalypti, and, after the rainy season covered with high grass. Springs of water are to be found on nearly all the islands throughout the year, and after the rains there is generally a profusion in the gullies and water holes. Thursday Island being so small is but poorly provided, and the inhabitants store up rain water in tanks to meet their necessities during the dry season, the water in the water holes being unfit for human consumption.

Thursday Island is one and a half miles long by about three quarters of a mile wide, and has a range of hills running half 
way through it in a north easterly firection, divided by a moderately broad valley crossing the island from north to south, and beyond this again there is a range of hills in the north east corner of the island, and another range in the south east corner. The highest point is 374 feet high. The settlement is situated upon Vivien Point, the south west extremity of the island, and extends along the beach for about half a mile from thence. The whole island is surrounded by a coral fringe reef.

After lunch I went on shore with three of my messmates, Lieutenants Ommanney and Allenby, and Mr. Hunter, midshipman. The two former I provided with nets and boxes, as they were anxious to help me to, as they said, complete my collection of the Australian butterflies, as this would be the last opportunity we should have of landing in Australia. We landed on the beach a little to the north east of the settlement, and walked to the valley which intersects the island, and across this to a range of hills which lie in the north east corner, and whose highest point, Rose Hill, is 223 feet. The valley was sparsely clothed with trees, the chief of them being Eucalypti, Casuarina, Banksia, Persoonia, \&c. Grass was abundant everywhere and in some places, especially at the edge of the forest, was breast high. There were also a few small acacia and cassia bushes, and some others I am unacquainted with, and here and there patches of vetches and other leguminose plants. The ground in many places was thickly strewn with volcanic blocks of stone, and these, hidden among the grass, made walking dangerous and unpleasant, and running almost out of the question. Most conspicuous objects in this valley were the coneshaped or castellated dwellings of the Termites. Some of them were from ten to twelve feet high, and eight or ten feet in circumference. They were evidently all inhabited for several pinnacles we kocked off were swarming with ants. The galleries were full of vegetable matter which apparently consisted of a mixture of bits of dead leaves, grass seeds and wood dust. The nests were composed of agglutinated sand, and were as hard as sand stone itself. It is astonishing how these little creatures can construct such wonderful dwellings. They must be several years raising one 
to a height of ten feet, for besides these large dwellings there were a number of smaller ones in course of erection, some only a few inches above the surface of the ground, but they had all an old weather beaten appearance. The galleries looked as if they had been lined with a dark reddish-brown shining substance, though this might have been produced by the traffic of such multitudes of

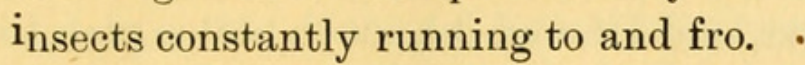

The first butterflies we saw were Junonia orithya which were fond of settling on bare patches on the ground, but they were so wary that they were very difficult to catch. There was a strong breeze blowing, and directly they took wing they were carried off at a great pace. Some of the eucalypti trees were in flower and proved attractive to several species of butterflies notably Papilio Polydorus and Eurycus cressida, butterflies which are very similar in habits and appearance when on the wing. One evidently mimics the other, and they fly in a slow floating manner, and are seemingly easy to catch. However, to day in this particular locality they were flying high out of reach among the topmost branches of the trees. Occasionally one descended and crossed the opening to another tree. This afforded a chance, and a rush was made after it, and it was amusing to watch how easily it avoided the frantic strokes of the net, and reached its goal in perfect safety, while its would-be captor stood still beneath the tree hot, panting, and probably with bruised shins, and in bad French, blessed Polydorus who was again feasting unconcernedly aloft. By the way has anyone noticed how closely Papilis anxctus mimics Acrcea Andromache in its flight and general appearance? I have upon several occasions mistaken the two, the former flying in the weak straight manner of the latter, and the colours and pattern of both somewhat resembling each other. Among the grass were several species of Terias, Satyridce, Lycanidae, and Hesperidce, and also a few Noctuce, Geometrce, and Pyrales, but on the whole MicroLepidoptera were far from plentiful.

As soon as we reached the edge of the forest the aspect of affairs changed, and butterflies became decidedly more numerous. Here we separated, my companions keeping outside, while I scrambled 
up the side of the hill until I got well within the shelter and shade of the trees. It was difficult walking for the grouud was covered with large loose stones, which were more or less hidden by the undergrowth so that it was necessary to be careful and look where one was going to. Once or twice I narrowly escaped a fall as I was eagerly pursuing some attractive species, and usually, upon these occasions, the insect was lost, and I found it a much better plan to walk along quietly or stop altogether when I reached a likelylooking spot, for butterflies often come quite close if one keeps perfectly still. The most abundant species in the forest were Papilio Polydorus, Hypolimnas alimena, and Euplcea Sylvester, but perhaps I had better at once proceed to give a list of the species seen and captured with remarks thereon, instead of a rambling disconnected account.

Ornithoptera Priamus. Linn., var. Pronomus. Gray. Three or four of these most magnificent butterflies were seen, and a pair, a male and female in perfect condition were captured. I was also fortunate enough to find two chrysalids and two full grown larvæ, and saw many smaller larvæ which I did not take as their food plant will not keep fresh for more than a couple of days on board ship. The larvæ were feedirg upon a kind of Ipomcea which was twining itself among and over the brushwood, some at a considerable height while others were feeding upon portions of the plant which were trailing on the ground, and I nearly trod upon one of the largest larvæ. The following is a description of a full grown larva.

Length two and a-half inches; tapering slightly towards each extremity; central segments thickened; comparatively short and obese; smoky black with a tinge of madder purple; head black and shining, with a narrow white $\mathrm{v}$-shajed mark on face; upon the crown of the second segment a crescent-shaped shining black plate, and between this and the head is the nuchal aperture, through which, when the larva is irritated, is emitted a pair of short thick carminecoloured tentacles; a subdorsal row of finely pointed spines on each side, the spines rather long, and those on the posterior segments pointing backwards; tips and base of spines black, intermediate 
portion scarlet; except on eighth segment, where the base of spine is white and from thence springs a broad oblique white stripe pointing forwards and terminating at the spiracular region; a row of black spines just below the spiracles; upon third, fourth, and fifth segments an additional spine between the subdorsal and spiracular row; a short black blunt tubercle on second segment upon each side of the face; a short black spine above each leg and claspers, which are shining black. The chrysalis, which is of an amber brown coluur, is slightly angulated, with a blunt subdorsal black-tipped spine on each side of the abdominal segments, and some small black spines on back of thorax; a large and almost triangular orange-yellow blotch upon back of anterior abdominal segments; wing sheaths dark reddish-brown, with the nervures well-marked.

These larvæ differed in no way from larvæ I have taken at the Duke of York Islands and New Britain, and which produced the blue variety Urvilliana, Guer., and the usual golden-green form, and I feel quite convinced that Kirby is correct in referring the five Australian varieties, and several others from New Guinea, Woodlark Island, Batchian, \&c., to Papitio Priamus, Linn., of which there is little doubt that they are merely local varieties. The Chrysalids are also indentical. Those I found were attached to the midrib of a very large leaf of some forest tree, and sometimes at a considerable distance from the food of the larvæ. Before suspending itself the larvæ takes care to securely fasten the stem of the leaf at its base to the branch of the tree with strong threads of silk.

Papilio Polydorus, Linn. One of the most abundant species met with. It flies in a light airy manner, generally quite straight like Eurycus or Acrcea and appears to be a particularly easy butterfly to catch, nevertheless it has a trick of dropping suddenly, or twisting to one side, as one makes a stroke at it, and instead of having it in your net, as you confidently expected, you see it hurrying off among the brushwood or careering aloft far out of reach

Papilio erithoneus. Cram. One or two seen. 
Papilio capaneus. West. Several observed, and one or two worn specimens captured. Young larvæ upon.

Papilio erectheus. Don. Common, and larvæ of various sizes upon orange trees in the garden of $\mathrm{Mr}$. Chester, P.M.

These specimens were of the New Guinea form, which is larger and rather differently marked than those from New South Wales.

Papilio Sarpedon. Linn. Several seen. A rapid flyer.

Papilio Agamemnon. Linn. Two or three seen and one captured.

Eurycus cressida. Fabr. Numerous.

Terixs australis. Wall.

$\left.\begin{array}{l}\text { Terias hecabe. Linn. } \\ \text { Terias. Sp. }\end{array}\right\}$ Common amongst high grass, \&c.

Pieris ega. Boisd. One male only.

Callidryas crocale. Cram. Several.

Danais affinis. Fabr. Not uncommon in the forest where it was fond of alighting upon the extremities of dead twigs, a habit which is common to all the Danaince.

Danais Petilia. Stoll. Common, but local.

Euplaca sylvester. Fab. Very common in the forest where it delights to sit in little family parties upon some dead bough.

Euplcea. Sp. Possibly a local variety of tulliolus, Fabr.

Junonia orithya. Linn. Common, but very wary and difficult to eatch.

Junonia vellida. Fabr. Common.

Precis zelima. Fabr. Several.

Rhinopalpa sabina. Cram. This fine species was not uncommon in the forest, and was in good condition. They were usually to be found in pairs, though sometimes they were in family parties of six or seven, and were fond of settling upon the underside of a large leaf near the ground, and flew out suddenly as one passed. As a rule, if one kept quiet, they almost invariably returned to the same spot.

Doleschallia bisaltida. Cram. Common. This butterfly, during the hottest part of the day, flies high and keeps well out of reach, but towards the evening, or when passing clouds obscure the sun, 
it descends and may then often be seen at rest on the underside of a leaf, when they may be easily caught if one approaches quietly. They are very pugnacious in their habits. One will take up its position upon a leaf at the extremity of some lofty branch and from thence starts off and gives battle to every passing butterfly, returning, after the encounter, to its original position.

Hypolimnas alimena. Linn. Plentiful and in fine condition.

Hypolimnas lasinssa. Cram. Common.

Neptis consimilis. Boisd. This pretty species was tolerably numerous. It flies in a very airy manner, giving three or four flaps with its wings and then floats gracefully to a leaf where it settles with wings fully expanded.

Neptis Shepperdi. Moore. The above remarks apply to this species also.

Melanitis Leda. Linn. A few only.

Mycalesis Perseus. Fabr. A few, but in poor condition.

Mycalesis terminus. Fabr. Common and in fine condition. These two species were found among high grass by the edge of the forest.

Ypthima arctors. Fab. Common with the above.

Canonympha. Sp. Common. This species also occurs near Sydney; but is unnamed in the local collections I have had access to.

Lyccena platissa. Herr. Schaff. Common.

Lyccena Salamandri. Macleay, W. A few.

Lyccena pygmcea. Snell. One example.

Lyccena. Sp., near Erinus. Fabr. One only.

Lyccena. Sp. Three examples.

Lycana. Sp. One example.

Hypochrysops anacletus. Feld. Three specimens of this beautiful species.

Hypochrysops Apelles. Fabr. One example.

Hypolyccena phorbas. Fabr. Several.

Amblypodia centaurus. Fabr. This brilliant species vas common flying to and fro in front of low bushes. It was difficult to obtain in good condition as it is very pugnacious in its habits, and both sexes are to be continually seen engaged in warfare. 
Amblypodia micale. Blanch. Two or three.

Ismene exclamationis. Fabr. Several.

Ismene. Sp. Several.

Pamphila aujiades. (?) Feld. Several.

Pamphila. Sp. One or two.

Pamphila. Sp. Several.

Apaustus agraulia. Hew. Common.

The above forty-eight species were the result of an afternoons collecting at $\mathbf{I}$ believe a not very favorable time of the year. If so much was done in such a short time it is reasonable to suppose that the list would have been very much increased if I could have had a few more days collecting and if it had been at a more favorable time of the year. From what I saw of Thursday Island I should judge that the larger islands, which are all well wooded, particularly Prince of Wales Island, would produce a greater variety of Rhopalocera, and all the species that have been taken at Cape York and other parts of the North Coast of Australia would be found upon them as well as many New Guinea species which up to the present time have not been recorded as Australian. I can imagine no better place than Thursday Island for a collector to make his head quarters for a couple of months for there could be no difficulty in working the other islands as they are all easily accessible by boat, and there are houses upon all of them so that comfortable accommodation could most likely be obtained. I am confident that many new species would reward a diligent collector.

In the above list it will be observed that many common species that ought to occur on this island were not observed upon this occasion, such as Pieris teutonia, Danais chrysippus, Danais erippus, and others. 


\section{$2 \mathrm{BHL}$ Biodiversity Heritage Library}

Mathew, Gervase F. 1885. "An afternoon among the butterflies of Thursday Island." Proceedings of the Linnean Society of New South Wales 10, 259-266. https://doi.org/10.5962/bhl.part.17925.

View This Item Online: https://www.biodiversitylibrary.org/item/30482

DOI: https://doi.org/10.5962/bhl.part.17925

Permalink: https://www.biodiversitylibrary.org/partpdf/17925

\section{Holding Institution}

MBLWHOI Library

\section{Sponsored by}

MBLWHOI Library

\section{Copyright \& Reuse}

Copyright Status: NOT_IN_COPYRIGHT

This document was created from content at the Biodiversity Heritage Library, the world's largest open access digital library for biodiversity literature and archives. Visit BHL at https://www.biodiversitylibrary.org. 